\title{
Crime Mapping and Geographical Information Systems in Crime Analysis
}

\author{
Murat Dağlar ${ }^{1}$ \\ Uğur Argun ${ }^{2}$
}

\begin{abstract}
As essential apparatus in crime analysis, crime mapping and Geographical Information Systems (GIS) are being progressively more accepted by police agencies. Development in technology and the accessibility of geographic data sources make it feasible for police departments to use GIS and crime mapping. GIS and crime mapping can be utilized as devices to discover reasons contributing to crime, and hence let law enforcement agencies proactively take action against the crime problems before they become challenging. The purpose of this study is to conduct a literature review of Geographical Information System and Crime Mapping in Crime Analysis and to propose policy recommendations regarding to implementation of crime mapping and GIS. To achieve this purpose, first a historical evaluation of GIS and crime mapping will be rendered and then the importance of place will be explained in terms of assessing crime problems accurately.
\end{abstract}

Keywords: Crime Analysis, Geographical Information Systems, Crime Mapping.

\section{1- Introduction}

Deciding a policing method is always influenced by some facts of place. Jurisdictions, zones, and incident locations are all related to geography. From pin maps to modern crime maps, mapping has always been an important element of law enforcement. Geographical Information Systems and crime mapping are only a more developed and modernized implementation of traditional types of things that law enforcement agencies have always done. In today's world, police duties are assisted by high technologies such as Geographical Information Systems and crime mapping.

Block (1995) note that pin maps have been seen in the police chiefs' rooms since the pin was discovered. Those maps were serving to demonstrate which areas were affected by crimes and in what kinds of places they were occurring at a glance. The developments in computer hardware and software have given further momentum to the use of maps. Many law enforcement agencies use crime maps and GIS thanks to this technology; this enhances the ability of police executives in making reasonable decisions about patrol assignments, better personnel policies, and proactive crime prevention programs.

In practice, GIS and crime mapping are used to find out the question "Where?" such as "Where should we focus efforts to catch a serial killer?" or "Where should we build a new police station to fight the crime problem?" or "Where is crime highest?" By analyzing the data provided from various sources, users at various organizational levels can make observations, conclusions, and policies. Heikkila (1998:351) defines Geographical Information Systems as "GIS is an organized

${ }^{1}$ Ph.D., Nigde Police Department, muratdaglar1974@yahoo.com

2 Ph.D., Ankara Police Department, $\underline{u}$ argun@hotmail.com 
Dağlar, M. \& Argun, U., (2016). Crime Mapping and Geographical Information Systems in Crime Analysis. International Journal of Human Sciences, 13(1), 2208-2221. doi:10.14687/ijhs.v13i1.3736

collection of computer hardware, software, geographical data and personnel designed to efficiently capture, store, update, manipulate, analyze and display all forms of geographically referenced materials." GIS not only has the potential of storing the data, but also has the capacity to create a map that makes the data visible.

\section{2- Literature Review}

\section{Crime-Place Relationship and Role of Place in Assessing Crime}

Brantingham and Brantingham (1991) note that one of the most important aspects of the crime is the location. The place of a crime and any other geographic information connected with a criminal incident can give a lot of information about characteristics of possible criminals, assist in the design of prevention, assist in the assessment of programs, and help get a better perspective of environmental reasons that may be related to criminal incidents. The sites of incidents are necessary to analysts who are concerned with recognizing regions containing a high level of crime.

Even a person who has no education about criminal science knows that crime is not at the same level in different locations. In nearly all cities, there are some high level crime places and low level crime places. This vital fact was realized by some researchers nearly two hundred years ago. These researchers, rather than being concerned with the criminality of individuals, were interested in the high criminality of places such as cities, counties, states or towns. These scholars tried to understand the reasons for crime rate differences in different places and if these differences in levels of crime were because of the individuals who lived in those areas or because of the features of these places. In this concern, it is believed that the importance of places was discovered a long time ago in criminal science.

France published the first crime report based on the systematically collected data from geographical units, called "Compte general de l'administration de la justice criminelle en France"(Beirne, 1993). Over time, this first crime report gained attention from some French researchers. These scholars analyzed the distribution of crime across regions with differing ecological and social characteristics (Quetelet, 1842). One of the most famous researchers Adolphe Quetelet carefully analyzed the data of "Compte general de l'administration de la justice criminelle en France." He understood that despite the fact that periodically obtained crime data of a region are generally regular, the crime data of different regions are not similar or at the same level when compared to each other. This finding convinced researchers that the reason for different crime rates in different places is not just a feature of the individuals but also a feature of the places in which people live.

The concentric zone theory was one of the preliminary models, developed by Park and Burgess in 1925, to explain the spatial organization of urban areas. The sociologists at the University of Chicago wanted to understand the effects of the rapid social changes, particularly their moral effects or implications for social order. Park and Burgess introduced an ecological analysis of crime causation. Park and Burgess then examined area characteristics, instead of criminals, for their explanations of high crime. Thanks to their study, they created the concept of urban areas, which consisted of concentric zones which extended out from city center to the suburbs. According to the concentric zone theory every specific zone of a city had its own structure and organization, features and different kinds of residents.

Closely tied with the Park and Burgess's studies, Clifford R. Shaw and Henry D. McKay made another contribution to the study of crime and place (Shaw and McKay, 1942). Park and Burgess's studies influenced criminologists Shaw and McKay who were interested in applying the Parks and Burgess concentric zone theory to the study of delinquency in Chicago. These researchers, by using the collected data of criminals' addresses, made crime maps by using pins and calculated the rates of delinquency for various geographic zones of Chicago. After making similar kinds of maps of some other cities like Boston and Cincinnati, Shaw and McKay found that crime 
was concentrated at the center of city and gradually decreased in concentration when moving further away from the city.

Hot spots and Crime Prevention through Environmental Design (CPTED) are also very important fields in crime prevention in terms of crime-place relationship. Crowe (2000:1) explains that "the proper design and effective use of the built environment can lead to a reduction in the fear of crime and the incidence of crime, and to an improvement in the quality of life." Hot spots studies are also another trendy approach to crime geography. Work by Sherman, Gartin and Buerger (1989) found that just a small percentage of addresses generated over half of all calls for service. These kinds of places are called "crime hot spots." According to the hot spot approach, much crime is occurring in specific locations, and other places are comparatively crimeless areas. In other words, crime clumps in some zones and is absent in others. Based on hot spot research, some of the scholars claim that if law enforcement agencies focus their concentration on these highcrime areas, many crime problems may be diminished more effectively.

Moreover, if some important police strategies are analyzed, it can be easily understood that these policing strategies are highly place-oriented approaches to crime. Since researchers accept the concentrated nature of crime, policing strategies are also going towards place-based policing implementations such as community-oriented policing, problem-oriented policing and team policing. In these kinds of policing strategies, generally police officers are responsible for an assigned geographical area in order to get familiar not only with people but also the place in which they work.

All in all, the vital importance of the place-crime relationship, along with technological developments, leads modern police agencies to use GIS and make their jurisdiction's crime maps. As an essential part of crime analysis, GIS and crime mapping is considered one of the most important elements of crime analysis that gives timely and significant crime information to police executives.

\section{History of Geographical Information Systems and Crime Mapping in Policing}

GIS has been around in manual form for a long time. French cartographer Louis Alexander Berthier drew up a map of the 1871 Battle of Yorktown in the American Revolution which contained hinged overlays showing troop movements (Star and Estes, 1990). Such manual information systems were useful in their time despite the limitations, but it was difficult to use them because of some problems. There were no standardized scales and the information was not always up-to-date (Rogers and Craig, 1996).

Weisburd and McEwen (1997) illustrate a good example of an incident of early crime mapping implementations in their study. Guerry, an attorney and Balbi, an ethnographer, created maps of crime in relation to violence and property crime types by applying France's census data from the years 1825 to 1827 . The data of criminal statistics and demographic information were integrated. As Weisburd and McEwen explained;

Comparing these maps, they found that the north-eastern portion of France... was better educated, that areas with high levels of crimes against property has low incidences of attacks on people, and that the areas with more property crime were populated by people with higher levels of education (1997:5).

Weisburd and McEwen say that, with their maps, Guerry and Balbi found that the spatial comparison showed an inverse connection between the education levels of the resident population and regions of violent crime.

By the mid-nineteenth century, the mapping of the distribution and demography of crime had begun. Garland (1997) says that during the nineteenth century "dangerous places" research and studies were very common. In this concern, pin maps have been used in police departments for many years as geographical information pattern analysis (Block, 1995). In these kinds of maps, classically, pins are put on a map showing crime. These maps can provide very good information to officers for the density and allotment of crime. The observer may get a very good overall picture of 
crime locations and types. In their traditional forms, however, pin maps are rather cumbersome and time-consuming to assemble. While they are renewed, the former crime patterns are gone. Additionally, pin maps might be too hard to understand while several kinds of crime, usually symbolized by pins of different colors, were mixed together. In other words, in the past, computers were not used as much as today in mapping. In the past, the maps were the spatial databases. In order to produce new information from maps, people had to read and study them with a great deal of effort. There were also restrictions of memory without computers. However, GIS has the capacity to store as much data as the computer hardware can permit. GIS can combine, add, subtract, multiply and divide the data and perform many other such operations. With GIS, the police may answer very difficult questions. Moreover, the system combines geographic information with crime statistics.

Although the computerized mapping started in the military first, today police are using it to map crime very commonly. GIS and crime mapping are finding a lot of applications within the police agencies not only in the United States but also in some other countries. Moreover, in the US a Crime Mapping Research Center was set up under the US Department of Justice in the 90's for assisting the police and crime analysts. Now the Crime Mapping Research Center has become known as an authority in the field of crime mapping.

\section{3- GIS and Crime Mapping as Crime Analysis Method and Their Functions in Policing}

"Why does it make sense to map crime? Our goals are to reduce and prevent crime, to reduce suffering by victims, to punish guilty, and to direct our limited resources where they can do the most good. Mapping helps us to achieve these goals. Mapping enables us to identify crime-ridden areas to not only direct resources, but ultimately to reduce crime and prevent new crimes from occurring. Mapping is also used to support investigations to apprehend suspects so that they are unable to cause additional harm to future crime victims. And mapping is used to support prosecution efforts by demonstrating defendants' movements and activities leading up to and following their criminal acts." (Arlington, Virginia, 1999)

Janet Reno

Attorney General of the United States

In these days, policing is influenced by a lot of new movements and trends, such as proactive policing, community policing, problem-oriented policing, and crime analysis. These new policing approaches are generally accepted by law enforcement agencies. Now that one of the most important elements of these new policing movements is crime analysis. It may be wise to give some brief information about crime analysis before mentioning crime mapping and GIS functions or benefits because GIS and crime mapping are accepted as commonly implemented crime analysis methods. So, what is crime analysis specifically?

Crime analysis is believed to have developed from problem-oriented-policing which is a popular policing trend intended to find out patterns of crime, discover solutions and find the resources necessary to address the problems. In this concern, it is accepted that crime analysis is required to be able to reach the goals of problem-oriented-policing, which are to find out problems and their cures and assess the results.

Some scholars have examined the mechanics of crime pattern recognition, a duty that some assert is the heart of crime analysis (Goldsmith, McGuire, Mollenkopf and Ross, 2000). Crime analysis is explained by Gill (2000) as the study of finding patterns and connections between crime data and other pertinent data sources to prioritize and target police activity. Some other scholars explain the essential operations of law enforcement crime analysis in a how-to manual format and draw from the former studies (Reuland, 1997).

Simply, crime analysis is a policing job which is aimed at identification and analysis of crime issues in order to find solutions to crime problems. In policing, crime analysis indicates that the police officer or person or unit in a law enforcement agency is responsible for processing data and 
providing information to that the agency. Hence, the agency can use the information for reducing, preventing, and solving crime issues and disorder. To achieve this, police calls for service, arrest reports, and crime reports are used as important data by crime analysis units. Then, in light of their findings, crime analysis units work with their police agencies to develop effective ways and tactics to answer to the crime and disorder.

According to Boba (2001:9) crime analysis means "the qualitative and quantitative study of crime and law enforcement information in combination with socio-demographic and spatial factors to apprehend criminals, prevent crime, reduce disorder, and evaluate organizational procedures." In light of this definition crime analysis has four aims. Helping to arrest criminals is one of the most important purposes of crime analysis. For example, an investigator may have a homicide case in which the possible criminal has a specific tattoo on her or his body. The police analysis unit can help investigators by checking a database for finding criminals who have the same tattoo. One other purpose of crime analysis is assisting field officers with crime prevention. If a residential area has theft problems, the crime analysis unit may help the police by conducting spatial analysis of theft, analysis of how, when, and where the theft happened, and analysis of what kind of things were taken from victims. Diminishing disorder is the third purpose of a crime analysis unit, accomplished by performing research and analysis of disorder indicators. The last purpose is helping police agencies with organizational decisions such as predicting personnel needs, resource allocation, the estimating of crime prevention implementations, and arranging police zones.

The Massachusetts Association of Crime Analysts suggests that (www.macrimeanalysts.com) crime analysis units should have the following abilities:

A solid understanding of criminal behavior, knowledge of the analyst's particular jurisdiction, knowledge of research methods, ability to collect, manage, collate, and query data, ability to understand and synthesize crime information, critical thinking skills, ability to calculate descriptive, inferential, and multivariate statistics, and to create meaningful charts and graphs based on those statistics, understanding of demographic analysis, strong computer skills, including databases, desktop publishing and word processing, spreadsheets, and statistical packages, ability to use a Geographic Information System and a thorough understanding of spatial analysis and spatial statistics, presentation skills, interpersonal communications skills.

Considering all these duties, a crime analyst serves as a blend of an information systems expert, a criminologist, a researcher, a planner, and a statistician for a law enforcement agency.

There are five types of crime analysis (Boba, 2001). The tactical one gives information to help operational staff in the discovery of specific crime movement and in the apprehension of offenders for instant criminal cases. To present important findings of crime analysis units to law enforcement administration, city council, city hall, and citizen groups for informing them is administrative crime analysis. Analysis to determine long term patterns of crime activities is accepted as Strategic Crime Analysis. Crime analysis which is used to find out organized criminal actions in terms of individuals, events, and properties is intelligence analysis. Lastly, analysis which tries to develop patterns that will assist in solving current serial criminal activities is criminal investigative analysis.

Because of its very important functions, crime analysis is gradually spreading out among police agencies in the United States. This spreading out of crime analysis is increasingly promoted thanks to the improvement and utilization of complicated computer technology and the allocation and commitment of resources to this area of practice (Rich, 1996). Moreover, a lot of law enforcement departments are creating dedicated crime analysis divisions so that they make information about police services more helpful and improve dissemination. These units' specific duty is only collecting and analyzing information from all sources, in order to unearth patterns or connections in the data for management or operational purposes. On the other hand, some agencies are looking for high-tech solutions to help them with efficient implementations of various specialized crime analysis programs. These software-based hi-tech assisted programs help police in conducting effective crime analysis. For example, International Association of Crime Analysts 
(IACA) is committed to a continuing process of professionalization through standards and knowledge development and made crime pattern definitions for tactical analysis.

As an important part of crime analysis, geographic information systems and crime mapping are software applications, utilized by lots of disciplines and occupations including policing. GIS has the unique capacity to overlay, in digital map layers, different data sources, such as police calls for service, arrest reports, crime reports, the location of specific sites, and even citizen complaints in order to use them for analysis. Olligschlaeger (1997) notes that GIS is providing a practical apparatus in police agencies for the analysis of huge amounts of information, which gives a profound understanding of crime and its reasons.

"Database management, spatial analysis and data visualization" are generally accepted as three important roles of GIS and crime mapping. Crime mapping and GIS provide the ability of connecting criminal behaviors and their many features with their geographic position thanks to the combined presence of the three components. These components can also achieve overlay functions that combine the place of crime events with the characteristics of the population of the regions in which they take place. Currently, other than GIS and crime mapping, no other implementation has the ability to proficiently achieve the blend of these types of analysis.

One other practical benefit of GIS and crime mapping is allowing law enforcement officers the ability to ask more important and necessary questions about crimes and their specific jurisdictions. As a result, police officers whose duty is patrolling may assess in which specific places they need to patrol and to which places they especially need to pay attention in order to overcome crime in their zone. Additionally, mapping can provide specific information on crime and criminal behavior to the general public (Saddler, 1999). By giving specific information about crime components to the public, crime mapping and GIS give opportunity to the community to help police departments and participate in the prevention of crime in their neighborhoods. In this sense, it connects police and neighborhoods to each other.

One vital benefit of crime mapping and GIS is preparing police departments for future crime problems in their jurisdictions by giving opportunities to the researchers to foresee future crime patterns. Consequently, crime mapping and GIS can be used for deciding the proper place for new facilities according to the future crime problems. As usage of crime mapping and GIS increases day by day, law enforcement departments will use it as a functional device to find out which place is best for setting up new police check points, headquarters, substations, and other facilities.

A daily example usage of crime maps is implemented by the sheriff's department of San Bernardino County, California. This police unit uses crime mapping to show where some recorded sex criminals dwell. In this implementation, officers find out the residence of child sex offenders on the map, and then they draw a buffer zone around each school to control how close the identified criminals stay to these possible victim areas (http://www.ojp.usdoj.gov/ovc/publications/infores/geoinfosys2003/cm3b.html). Likewise, a victim service provider may utilize GIS to track and map the place of victims who were issued protection. 'To do so, the distance of possible attackers' residences can be calculated to the victims' residence and necessary patrols can be assigned to required spots.

Ratcliffe (2002:214) gives concise information about the benefits of crime mapping-usage for police departments by referencing Wartell and McEwen (2001) as follows:

1. Providing crime maps on the Internet may provide a saving in police workload,

2. Increased community knowledge about crime may increase community co-operation,

3. Maps can assist in community policing and problem solving,

4. Maps can increase public awareness of neighborhood problems,

5. Maps can facilitate partnerships with researchers and other agencies,

6. Data provision by the police service can help prevent its figures from being misinterpreted,

7. Maps and data increase police department accountability. 
As a result, GIS and crime mapping help a wide variety of problem solving and spatial decision-making applications in crime, crime patterns and crime locations (Saddler, 1999) and offer the opportunity to police departments to utilize a larger amount of information more intelligently (Nelson, 1999).

\section{4-Specific Implementations: Compstat and Geographical Profiling}

\section{Compstat}

Decision-making police managers in the police departments are practically utilizing crime mapping and GIS to facilitate their decisions on how to organize their man-power and other resources. The New York City Police Department uses GIS and crime mapping on a daily basis, and thus GIS has become an important element of the COMSTAT implementation. CompStat was started by New York City Police Department Police Commissioner William Bratton in early 1990. Since then, the program has been accepted as one of the most popular trends in policing. Compstat even won the 1996 "Innovations in American Government" award.

Compstat has been described by Walsh (2001:347) as a "goal oriented strategic management process that uses computer technology, operational strategy, and managerial accountability to structure the manner in which a police department provides crime-control services." George Kelling and William Sousa (2001:2) have described it as "perhaps the single most important organizational/administrative innovation in policing during the latter half of the twentieth century."

Although it is not a crime mapping method, COMPSTAT used GIS and crime mapping techniques during conference presentations. As a word compstat is abbreviated from computerstatistics $^{3}$, hence the most important characteristic of this program is usage of computerized statistics. In the New York Police Department's crime-strategy meetings, these statistics are evaluated by police executives in order to better locate and deploy resources. Specific problems are displayed and analyzed by using crime mapping and GIS in these meetings. The GIS and crime maps aid police executives in perceiving crime patterns in relation to neighborhood demographics and area boundaries. In these periodic meetings, especially, groups of criminal incidents and clusters become very noticeable to high level police managers.

Police managers focus resources on fighting crime issues after they analyze problems during the compstat process. For example, if a police commander notices crime increasing near the football stadium on game days he or she can reassess his or her police department policing response on those days in that area. Namely, GIS and crime mapping assist the New York Police Department in compstat process in discovering crime hot spots. That is to say, GIS helps to identify the problem by presenting crime event locations. After that, necessary resources may be reallocated more properly. Additionally, compstat re-engineers law enforcement administration by holding police executives directly accountable for crime levels in their jurisdictions.

Willis, Mastrofski and Weisburd (2004) says that they checked all the literature and found six core elements about compstat mission clarification: internal accountability, geographic organization of operational command, organizational flexibility, data-driven analysis of problems and assessment of department's problem-solving effort and innovative problem-solving tactics.

Because all of the major recommendations suggested by current organizational development specialists are combined by Compstat, many departments are gradually starting compstat policing in their departments. Silverman (1996) notes that because of much national publicity about crime declining and compstat usage in New York, implementation of compstat has increased in other police departments. According to Willis, Mastrofski and Weisburd (2004), since COMPSTAT began in 1994, a third of big departments have started to use similar programs and 26

\footnotetext{
${ }^{3}$ In the late 20th century, police agencies and departments throughout the United States and in some areas of Britain began adopting computerized systems, known as Compstat (computerized statistics), that could be used to plot specific incidents of crime by time, day, and location (http://global.britannica.com, 2016)
} 
percent are planning to start. Grubler (1991) guesses that it takes the most rapidly diffuse technologies to grow to 90 percent expansion level.

Ahead of this implementations compstat using in policing ensured some modern policing applications. For example, MANAGER model of Arlington Police Department which tests the performance of police organization can be used in policing by getting inspired from compstat-like programs (Özdemir, 2012) or just depicted in a study (Yavuz and Tecim, 2012) in İzmir, Turkey, artificial neural networks and spatial decision system can be created to prevent crimes by analyzing GIS-based data.

\section{Geographical Profiling}

Whereas COMPSTAT is an operational management practice, geographical profiling is an investigative tactic. Namely, geographical profiling deals with the geographic activities of the serial criminals with a view to forecasting the location of his or her home.

According to Brantingham and Brantingham (1981), the background of geographical profiling is closely tied with some crime theories such as routine activity theory, opportunity theory, and rational choice theory. In general, these three theories of crime explain that lots of people live in a routine activity style. Specifically, people depart from their houses to work at around a specific time, travel from work to daily doings, and then from that to their house again. The main point in this process is that people in every community find specific places such as home, work, school, restaurants, bar, and movie where they usually spend their days and in which they feel comfortable and safe because of the sensation of being in familiar circumstances. Likewise, every individual criminal has their daily routines in their life while they committing crime.

Ratcliffe (2004), in his article, concisely relates criminals' daily routines to the routine activities of ordinary people with consideration of criminal theories and explains how geographic profiling uses this relation for investigating criminals:

“....offenders will have similar routine activities in their lives, but these areas of familiarity will also be the search areas for opportunities offend. While Cohen and Felson's Routine Activity Theory can be interpreted as an indication of victim behavior (Robinson 1999), crime pattern theory can be considered of the offender equivalent, indicating areas of likely criminal behavior. At the coming together of the victim and offender is a rational choice by the offender to take advantage (or not) of any criminal opportunity that is presented (Clarke and Felson 1993).

Geographic profiling pulls these ideas together to deconstruct a pattern of offending elicited form victim information and crime scene examination resulting in a map if crime sites such that each point represents a location where the offender was known to be at one point in time." (pp, 7374)

An important dimension of geographical profiling is studies about distance between offenders' home and crime spot. The research of the distance between a criminal's home and crime place has been an important issue in criminology for many years. Generally in these research studies, the distance between the offender's home and the location of the offense are taken as a dependent variable. A prime conclusion from studies is that most crimes take place in relatively close proximity to the home of the criminals. That is to say, the possibility of an offender choosing a particular target decreases with the distance of the target from his home (Capone and Nichols, 1976).

By using this knowledge, (crimes happen in generally close proximity to the house of the criminals) and crime site clues, geographical profiling may surmise the probable places of the criminals in a specific zone. Then it may create a map of that probable location to determine the criminal's likely place of residence. 
Despite the fact that geographical profiling has been mostly implemented for serial homicide and arson cases, other uses of geographical profiling are also possible. It may be utilized for suspect prioritization, patrol saturation, improvement to police information systems, linking with an outside agency database, and most recently to target DNA testing of large populations (Rossmo, 2000).

\section{5-Controversial Issues in Geographical Information Systems and Crime Mapping}

Like every good technology and implementation, the GIS and crime mapping has some problems and difficulties. Weisburd and McEwen (1998) note that lots of academics and police have been annoyed by the contradictions between promises of digital crime mapping and some negative points of developing such maps with criminal justice information. Mainly these negative points or controversial issues and problems can be enumerated as expensive cost of implementation, resisting-police-culture consideration, difficulties about finding out exact locations of crimes, accurate data considerations, transgression invasion of people's privacy, negative effects to social and economic life, aftermaths of "spatial labeling" and some technical difficulties.

The expensive cost of GIS and some resistant police cultures can make usage of GIS and crime mapping technologies difficult. High technology implementations are always expensive. Rogers and Craig (1996) emphasize that economic issues are the main factors when deciding to implement GIS or crime mapping. This can be an important difficulty for development of this vital technology, especially in small agencies that cannot afford to implement GIS and crime mapping. For some police agencies, there are also some cultural and political considerations. Such police cultures refuse to use the technology because of resistant and general lack of knowledge in technical matters. They chose to be dependent more on personnel experience than on statistical based information (Block and Green, 1994).

Finding out exact location and accurate information of crimes are two other problems when using GIS and crime mapping. Recording the exact location of a crime is a vital issue. Some might assume that this would be a fairly uncomplicated matter in that the police would simply record the place in which a crime occurred. Yet, it is not that easy. For example, if a knife attack occurs in a bar, must this be recorded under the name of the bar or its address? Or if the trouble begins in a specific location and moves to another place, how should the location of the incident be entered into the system? Imagine that for a while, how the location can be entered into the system if the incident location has two doors which may open to different streets, or if a location has no door number? Moreover, recording addresses properly is a very sensitive point because even the simple miss-spelling of an address can cause problems in computer programs. Ratcliffe (2001:216) enumerates 10-important points about the geocoding errors problems;

1. Out-of-date street directories that do not recognize new addresses or roads.

2. Abbreviations of street and road names (for example, 'gdns.' in place of 'gardens') that cannot be recognized by geocoding software.

3. Local name variations that do not match database entries.

4. Address duplication problems that are caused by dozens of streets with the same name across a city.

5. Non-existent addresses caused by typographical errors (for example, ' 3700 Chestnut Street' that should read '370 Chestnut Street').

6. Line simplification that does not reflect the true curves of a street and places geocoded points in the wrong place. Line simplification is the process of using sections of small, straight lines to represent curved and winding roads. It is commonly done with GIS to reduce file sizes and to simplify the visualization of bending road $s$ and shapes.

7. Noise in the address file that causes geo-coding software to skip records. Additional terms in addresses such as 'outside 12 Smith Street' or 'near 12 Smith Street' can be unreadable to many geo-coding programs. 
8. The inability to geo-code non-address locations, such as $50 \mathrm{~m}$ along a street, or in a rural location a few miles from a town.

9. General geo-coding imprecision that places a point some distance from the actual address.

10. Ambiguous or vague addresses that make it impossible to identify an actual address.

Additionally, any geographic profiling may only be successful on the condition that those producing data have accurate records. Yet, the crime information which is entered into the system may not be exactly true every time. For example, people don't always report the entire criminal incident or report it inaccurately. The police also sometimes may not do their job accurately while writing report information. In addition, especially for hot spot implementation, calls from the public are not only about crime, but also for services which can be trivial things such as missing animals or escort services. According to Ainsworth (1995), scientific research studies have revealed that, in policing, citizen's calls are not always related to real crime problems, but other types of calls for service. In this condition, it can be difficult to identify any place as a high-crime place if the demanded requests are not classified as real crime issues and other police services.

Another controversial issue is the privacy of the people. GIS and crime mapping may cause transgression of privacy and confidentiality of people's lives. Specifically, some detailed information should be entered to the systems while a crime map is being prepared such as gender, age, time, place, ethnicity, and age for criminals or victims. In this case, overlaying specific crimes with all this information may inadvertently reveal the identity of a victim or possible suspects. Ratcliffe (2002) asserts that even when a specific address is not on hand, the address could be accessible to people by making a dot on a map. Additionally, only a small number of people who become victims will offer information of their victimization to the law enforcement agencies knowing that they could be recognized with small efforts by others on the Internet. For example, how many rape victims want his or her address or identification being reached by the public on the internet?

Putting crime maps onto the internet is another controversial issue in terms of its bad effect to those places which has more crime than the other places. One of the most important aftermaths is that when a high-crime region's map is published on the internet, it may directly influence insurance rates in that area. As a result, residential and commercial property prices may suffer. Also, a lot of qualified public service workers and employees may decide to work in another region in which the crime problem is not as bad which may affect the quality of services offered to that region. For example, imagine that if in that kind of case all the good teachers get jobs elsewhere and this affects quality of education available to schoolchildren in the region.

In his study Ratcliffe (2002:221) is discussing the "Spatial Labeling" notion which he identifies as, "negative impressions and stigmas can be attached to an area, with a knock-on effect on the tolerance to crime of the residents and people passing through the region." In other words, according to Ratcliffe labeling a region as high-crime-area causes a negative effect on that area as explained in Labeling Crime Theory. According to this crime theory the labels applied to people effect their manner, especially the application of negative or stigmatizing labels like "deviant, criminal or felon". These labels make criminal act out a self-fulfilling prophecy. As a result, a person who is labeled has little option but to obey the necessary meaning of that decision. Related to this issue, Grabosky (1996) explains the negative affect of identifying a place as "high-crime area":

The mere identification of a place as dangerous or rowdy sends a signal. Persons who are risk-aversive and who value tranquility will be inclined to avoid such a location, while those who would be producers and consumers of risk would be attracted to such a place. Where signals of danger do not initially reflect empirical reality, they may operate as self-fulfilling prophecy, transforming the image and reality of a place. (pp, 25)

One other concern about crime mapping is technical issues which the police agencies may face when they decide to set up a computerized mapping system. According to Mazerolle, Bellucci, and Gajewski (1997), the initial issue is to make a choice to set up a crime mapping system for 
street-level problem-solving officers or to set up it for crime analysts and police department planners. Even though, any crime mapping system can be beneficial for both groups in some degree, to get maximum benefit from crime mapping depends on which group is going to used it. In other words, according to Mazerolle, Bellucci, and Gajewski, any system demands, including data needs and types of inquiries will not be the same for street-level-problem-solving officer and crime analyst and police department planners. So, police departments which are intended to set up a crime mapping system must decide about the purpose of the system. Moreover, Mazerolle, Bellucci, and Gajewski add that some police departments may have not the ability to integrate PC mapping capabilities within mainframe computing environments. This is another challenging technical issue which needs investments.

\section{6- Policy Recommendations}

When the crime maps are on the internet, it is beyond the control of the police departments. That is why two important steps should be assured before publishing the crime map on the internet. These are data integrity that is used for creating the map and an explanation of limitations about the map published on the internet. Giving information about crime to the community differs from giving information to criminal justice professionals. Despite this, criminal justice professionals are generally aware of the limitations of criminal justice studies. People who do not have enough information about criminal justice are not knowledgeable enough to assess the crime distribution published on the internet. At that point, one of the most important responsibilities is on the crime map makers in police departments, in terms of not only rendering highest levels of data integrity but also giving some honest and satisfactory explanation about the limitation of the data and limitations of the methods they have used in mapping.

Because privacy is a vital subject, as much as a public right to information in a public information system, mechanisms must be devised to ensure privacy protection in order to balance the public right to information and privacy of the crime victim. For example, as an implementation, the individual identification may be just kept confidential during the necessary period of time and may be destroyed immediately after the required process is done. As in the following example, many techniques may be developed to assist crime map makers to protect identification and the addresses of crime victims or, if needed, for criminals'. Additionally, it is important that information or data should be used just for crime mapping or analysis purposes and this information must only be accessible to authorized staff for investigative purposes. That is why, the user of GIS, especially data layers, have to be aware of private and sensitive data and require precautions to protect people's rights and privacy.

Convincing the police about the necessity of GIS and crime mapping is another task to be done. They may need to be convinced that the geographical information system and crime mapping analysis tool is worth using. For technology-resistant police cultures, some presentation and education programs can be organized for breaking the resistance to these kinds of technologies. In order to prevent entering inaccurate and insufficient data to the system, some standards can be created for police usage. Additionally, police can be educated about the importance of giving accurate information to the crime mapping and analysis unit and about the importance of life privacy.

In order to prevent the bad effect of the "spatial labeling," the public must be informed about the complexity of crime distribution. Ratcliffe (2000) argues that information provided by researchers confirm that crime hot spots may change over time. This means any jurisdiction, which is considered a high-crime area, can be the safest place over time and also any place which is considered as low-crime area can be the most dangerous place. If crime map makers give satisfactory information about the changing-nature of high-crime areas, prejudice of public opinion against high-crime areas published on the internet may be reduced in some degree.

Is the internet the most effective method of sharing information of crime for the whole society every time? One other noteworthy implementation can be effective usage of television and 
other mass media for either distributing crime analysis findings or expounding crime maps of regions due to limited usage of internet in the community. Otherwise, only those with access to the internet will be able to make informed judgments regarding crime around their region.

Olligschlaeger (1997) asserts that the perception of geographic information systems and consequently all of the implementations about it are still relatively new to researchers and practitioners. That is why, it seems like additional work is necessary to improve some of the controversial issues.

Among these controversial issues in the field of GIS and crime mapping, especially negative effects of the "spatial labeling," deserve to be researched properly by scholars. As explained above, to label an area as dangerous has some really important aftermaths to the community of that area. Despite this obvious fact, there is not enough studies which aim to find out what can be done to eliminate the negative affect of "spatial labeling" in terms of economic, sociological, and criminological perspective. Concisely, there is a need for systematic scientific studies in order to remove aftermaths of spatial labeling.

\section{Conclusion}

Despite the high usage of Geographical Information Systems and crime mapping, it is still in a developmental juncture and some of the technical and ethical concerns wait to be resolved. In the United States, police enforcement units have a long history of using developed, innovative technologies to assist in preventing and solving crime. Computers and information systems for crime analysis are widely in use in many police departments.

The location of a crime and the use of geographic space by offenders are important components of the criminal event. That is why, the usage of GIS and crime mapping is vital for analyzing and identifying crime patterns and trends. In this concern, as indicated before, GIS and crime mapping support a broad variety of problem solving and spatial decision-making applications in crime and crime locations. GIS lets agencies utilize more information more intelligently.

It is certain that the above benefits, problems and policy implementations do not include everything about GIS and crime mapping. There may be many other benefits, problems, and policy recommendations required for police departments that use or intend to use this technology. Of course, to reach that new information requires new research and study.

\section{References}

Ainsworth, P.B. (1995). Psychology and Policing in a Changing World. Chichester: Wiley.

Beirne, Piers. (1993). Inventing Criminology: Essays on the Rise of "Homo Criminalis", Albany State University of New York Press.

Block, C.R. (1995). STAC Hot-Spot Areas: A Statistical Tool for Law Enforcement Decisions. C. R. Block, M. Dabdoub, and S. Fregly (eds), Crime Analysis through Computer Mapping, Police Executive Research Forum Washington DC, pp. 15-32.

Block, C.R., and Green, L.A. (1994). The Geoarchive Handbook: A Guide for Developing a Geographic Database as an Information Foundation for Community Policing. Illinois Criminal Justice Information Authority.

Brantingham, P.J. and Brantingham, P.L. (1981). Environmental criminology. Beverly Hills, CA: Sage.

Brantingham, P.J. and P.L. Brantingham (1991), Environmental Criminology (eds.). Prospect Heights, IL: Waveland Press.

Boba, R. (2001). Introductory Guide to Crime Analysis and Mapping, Report to the Office of Community Oriented Policing Services Cooperative Agreement.

Capone, D.L. and W.W. Nichols, Jr. (1976). Urban Structure and Criminal Mobility, American Behavioral Scientist, 20:199-213. 
Dağlar, M. \& Argun, U., (2016). Crime Mapping and Geographical Information Systems in Crime Analysis. International Journal of Human Sciences, 13(1), 2208-2221. doi:10.14687/ijhs.v13i1.3736

Clarke, R.V. and Felson M. (1993) Introduction: Criminology, routine activity and rational choice. In: R.V. Clarke and M. Felson (Eds), Routine Activity and Rational Choice, Vol. 5, pp. 259294. New Brunswick: Transaction Publisher.

Crowe, T. D. (2000). Crime Prevention through Environmental Design: Applications of Architectural Design and Space Management Concepts (2nd edn). ButterworthHeinemann, Oxford.

Encyclopaedia Britannica (2016), Retrieved on March 22, 2016, (http://global.britannica.com/topic/Compstat).

Garland, D. (1997). Of crimes and criminals: The development of criminology in Britain. M Maguire, R Morgan and R Reiner (eds.), The Oxford Handbook of Criminology, Clarendon Press, Oxford, pp. 11-56.

Gill, P. (2000). Rounding up the usual suspects? Developments in Contemporary Law Enforcement Intelligence. Aldershot: Ashgate.

Goldsmith, V., McGuire, P., Mollenkopf, J. and Ross, T. (2000). Analyzing crime patterns (eds.). Thousand Oaks, CA: Sage.

Grabosky, P. (1996). Unintended consequences of crime prevention. In: Homel, R. and Clarke, R (Eds.), Crime Prevention Studies, Criminal Justice Press, New York. Vol. 5, pp. 25-56.

Grubler, A. (1991). Diffusion and Long-Term Patterns and Discontinuities, Technological Forecasting and Social Change, 39: 159-180.

Heikkila, E. J. (1998). GIS is dead; long live GIS! American Planning Association. Journal of the American Planning Association, 64(3), 350.

International Association of Crime Analysts. (2011). Crime pattern definitions for tactical analysis (White Paper 2011- 01). Overland Park, KS: Author. (Retrieved March 23, 2016 from International Association of Crime Analysts http://www.iaca.net/Publications/Whitepapers/iacawp 201101 crime patterns.pdf.

Kelling, G. L., and W. H. Sousa. (2001). Do Police Matter? An Analysis of the Impact of New York City's Police Reforms. Civic Report no. 22 (December 2001): Center for Civic Innovation at the Manhattan Institute, http://www.manhattan-institute.org/html/cr 22.htm

The Massachusetts Association of Crime Analysts, (2012). What Is Crime Analysis? Retrieved on 22/03/2016, (http://macrimeanalysts.org/crime-analysis/)

Mazerolle, L.G., Bellucci, C., and Gajewski, F. (1997). Crime mapping in police departments: The challenges of building a mapping system. In D. Weisburd \&J.T. McEwen (Eds.). Crime Mapping and Crime Prevention (pp. 131-156).Monsey, NY: Criminal Justice Press.

Nelson, L. (1999). GIS : The powerful weapon for law enforcement, ESRI Arcuser Magazine Jan March 1999 Environmental Systems Research Institute, Inc. ESRI Web Site www.esri.com.Pilant, L. (1997, December). Computerized Crime Mapping. Police Chief, 60-69.

Olligschlaeger, A.M. (1997). Artificial Neural Networks and crime mapping. Crime Mapping, Crime Prevention. New York: Criminal Justice Press.

Özdemir, H. (2012). Compstat: Arlington (Teksas, ABD), Polis Müdürlüğü MANAGER Yönetim Modeli, (Ed. Sekine Özdemir ve Uğur Argun), Suç Önleme Sempozyumu Bildiriler Kitab1, Bursa Emniyet Müdürlügü Yayınları No:1, Bursa, ss. 310-330.

Park, R. and E. Burgess (1925). Urban Ecology Studies, CSISS Classics, http://escholarship.org/uc/item/6f39q98d\#page-2

Quetelet, A.J. (1842). Treatise on Man and the Development of His Faculties. Edinburgh, SCOT: W. and R. Chambers.

Ratcliffe, J.H. (2000). Aoristic analysis: the spatial interpretation of unspecific temporal events. International Journal of Geographical Information Science, 14/7, 669-679.

Ratcliffe, J.H. (2001). On the accuracy of TIGER-type geocoded address data in relation to cadastral and census areal units. International Journal of Geographical Information Science, $15 / 5,473-485$. 
Dağlar, M. \& Argun, U., (2016). Crime Mapping and Geographical Information Systems in Crime Analysis. International Journal of Human Sciences, 13(1), 2208-2221. doi:10.14687/ijhs.v13i1.3736

Ratcliffe, J.H. ( 2002). Damned If You Don't, Damned If You Do: Crime Mapping And Its applications. The Real World. Policing and Society, 2002, Vol. 12, No. 3, pp. 211-225

Ratcliffe, J.H. (2004), Crime Mapping and the Training Needs of Law Enforcement. European Journal on Criminal Policy and Research; 2004; 10, 1; Research Library pp. 65-83.

Reno, J. (1999). Crime Mapping and ESRI, in Crime Mapping News, Lew Nelson (ed), Volume 1. Issue 4, Fall 1999, Police Foundation, Washington, DC 20036

Reuland, M. (1997). Information management and crime analysis: Practitioners' recipes for success. Washington, DC: Police Executive Research Forum.

Rich, T.F. (1996). The Chicago Police Department's Information Collection for Automated Mapping (ICAM) Program. Washington, DC: U.S. Department of Justice, National Institute of Justice. NCJ 160764.

Robinson, M.B., (1999). Lifestyles, routine activities, and residential burglary victimization. Journal of Crime and Justice, 22(1), pp.27-56.

Rogers, R. and Craig, D.E. (1996). Geographic Information Systems: Computers in Law Enforcement. Journal of Crime and Justice, 16: 61-73

Rossmo, D.K. (2000). Geographic profiling. Boca Raton, FL: CRC Press.

Saddler, D. (1999). Why Map Crime?, Crime Mapping Research Center, National Institute of Justice, U.S Department of Justice, Washington, DC. www. ojp.usdoj.gov/cmrc,

Shaw, Clifford R., and Henry D. McKay. (1942). Juvenile Delinquency and Urban Areas. Chicago, University of Chicago Press.

Sherman, L.W., Gartin, P. R., \& Buerger, M. E. (1989). Hot spots of predatory crime: Routine activities and the criminology of We are indebted to Jerry Ratcliffe of the Depart- place. Criminology, 27: 27-55.

Silverman, Eli B. (1996). Mapping Change: How the New York City Police Department Reengineered Itself to Drive Down Crime. Law Enforcement News, (December15), http://www.lib.jjay.cuny.edu/len/96/15dec/html/12.html.

Star, J. and Estes. J. (1990). Geographic Information Systems: An Introduction. Englewood Cliffs, New Jersey: Prentice Hall.

Walsh, William. (2001). Compstat: An Analysis of an Emerging Police Paradigm. Policing: An International Journal of Police Strategies and Management, 24 (3): 347-363.

Wartell, J. and McEwen, J.T. (2001). Privacy in the Information Age: A Guide for Sharing Crime Maps and Spatial Data, Institute for Law and Justice, NCJ 188739, Washington DC,Retrieved March 24, 2016 (https://www.ncjrs.gov/pdffiles1/nij/188739.pdf).

Weisburd, D., \& McEwen, T. (1997). Introduction: Crime Mapping \& Crime Prevention. In D. Weisburd \& T. McEwen (Eds), Crime Mapping \& Crime Prevention (Vol. 8, pp. 1-21). Monsey New York: Criminal Justice Press.

Weisburd, D. and McEwan, T. (1998). Crime Mapping and Crime Prevention Studies (eds.) Volume 8. Monsey, NY: Criminal Justice Press.

Willis, James J., S. Mastrofski, and D. Weisburd. (2004). Compstat in Practice: An In-Depth Analysis of Three Cities. Washington DC: The Police Foundation.

Yavuz, Ö. ve Tecim, Y. (2012). CBS Tabanlı Suç Önleme Çalışmalarında Yapay Sinir Ağları Kullanılarak Mekansal Karar Sistemi Oluşturulması, (Ed. Sekine Özdemir ve Uğur Argun), Suç Önleme Sempozyumu Bildiriler Kitab1, Bursa Emniyet Müdürlüğü Yayınları No:1, Bursa, ss. 295-310. 